Kidney cancer, despite the constant upward trend in the incidence of this type of cancer (about $1.5-5.9 \%$ per year), is rather rare, representing approximately $2-3 \%$ of all adult cancers.

Since recently, drugs based on so-called targeted therapy play a decisive role in the treatment of patients with metastatic kidney cancer.

Prognostic and predictive factors can significantly contribute to prognosis assessment and the correct classification of patients to specific forms of causal treatment of kidney cancer. In addition to the most commonly used and widely known prognostic factors, grouped in the so-called Motzer model, new prognostic markers of this tumour are being sought. Preliminary reports indicate that there may be a promising role of factors that regulate the cell cycle and apoptosis, and agents from the group of hypoxia-induced proteins. The proliferation markers or proteins related to cellular adhesion can also be relevant. This article presents examples of markers from the first of the above groups of proteins, which on the basis of the performed analyses showed independent prognostic or predictive value in kidney cancer.

Key words: kidney cancer, targeted therapy, apoptosis-regulating factors, prognostic factors, predictors.

\section{Seeking new prognostic and predictive factors in patients with metastatic renal cell carcinoma - apoptosis- regulating factors}

\author{
Beata Młot, Cezary Szczylik, Piotr Rzepecki
}

Central Clinical Hospital, Military Institute of Medicine, Warsaw, Poland

Renal cell carcinoma (RCC) is a malignant tumour derived from epithelial cells of renal tubules. It remains the most common kidney cancer (85\%) and represents about $3 \%$ of all malignancies in adults [1].

Renal cell carcinoma is usually diagnosed in the $6^{\text {th }}$ or $7^{\text {th }}$ decade of life, but the average age of onset for this type of cancer is constantly decreasing. Kidney cancer is more common in men, the incidence ratio of men to women is $3: 2$ [2]. In Poland, in 2008, 1174 people were diagnosed with kidney cancer, and 609 patients died from this type of cancer [3-5].

Most kidney cancers are sporadic; only 4\% are tumours associated with genetic syndromes [2].

Renal cell carcinoma is a tumour resistant to conventional methods of oncological treatment: chemotherapy and radiotherapy. In the first clinical stage by TNM classification, the 5 -year survival rate is $70 \%$ to $90 \%$; it is $55 \%$ to $70 \%$ in stage II, 20\% to 30\% in stage III, and it does not exceed 10\% in stage IV [6].

At the same time, significant progress has been made in the treatment of this cancer in recent years. A decisive role in this respect has been played by modern medicines from the group of tyrosine kinase inhibitors, serine-threonine kinase inhibitors, and monoclonal antibodies, which have partially replaced immunotherapy with interferon $\alpha$ (IFN- $\alpha$ ) or interleukin-2 (IL-2), used until recently. This new group of drugs used in metastatic clear-cell renal carcinoma includes sorafenib, sunitinib, temsirolimus, everolimus, pazopanib and bevacizumab. Their mechanism of action consists in inhibition of the molecular processes responsible for the emergence, proliferation, and expansion of RCC cells, as well as inhibition of neoangiogenesis, which plays an important role in carcinogenesis and metastasis formation.

Renal cell carcinoma is a cancer in which, irrespective of the initial stage, the rate of clinical progression varies, hence the large role of predictive and prognostic factors in patients' qualification for specific forms of causative therapy. Based on the conducted and published research, prognostic factors which were shown to be important in RCC were grouped into a few criteria systems for determining the prognosis in order to optimize therapy in this type of cancer. The system which is most commonly used in clinical practice is the system published in 2002 according to the Memorial Sloan-Kettering Cancer Center (MSKCC), i.e. the so-called Motzer model, developed on a group of 670 patients [7].

Risk factors in renal cell carcinoma according to MSKCC (Motzer et al.):

- poor general condition in the Karnofsky scale $<80 \%$,

- adjusted serum calcium > 10 mg\% [calculated as (albumin level - 4 g\% the patient's albumin level in $\mathrm{g} \%) \times 0.8+$ total serum calcium concentration in $\mathrm{mg} \%$,

- lactate dehydrogenase activity $1.5 \times$ the normal value, 
- haemoglobin concentrations below the lower limit of normal for a given sex,

- nephrectomy not performed.

A classification of the patient groups based on the presence of risk factors according to MSKCC is presented in Table 1.

In 1996, Lopez Haninen et al., based on the analysis of a group of 215 patients, developed a cumulative risk scale. Each of the six most important risk factors that were established during the study was assigned a specific score. The total score allowed the patients to be included in a specific risk group [7].

Risk factors and cumulative risk scale in kidney cancer according to Lopez Haninen et al.:

- erythrocyte sedimentation rate $(E S R)>70 \mathrm{~mm} / \mathrm{h}-2$ points,

- lactate dehydrogenase $>280 \mathrm{U} / \mathrm{l}-2$ points,

- neutrophils $>6000 / \mu l-1$ point,

- haemoglobin < $10 \mathrm{~g} / \mathrm{dl}-1$ point,

- extrapulmonary metastases only - 1 point,

- bone metastases - 1 point.

Patient group assignment according to the cumulative risk scale is presented in Table 2 .

In the group of patients with metastatic kidney cancer in the course of causative treatment with new therapeutics, significant differences in progression-free survival have been seen, despite using the same form of therapy in patients with the presence of the same well-known prognostic and predictive factors. A challenge that remains is therefore the correct selection of patients for treatment with the new therapies, and predicting the effectiveness of the planned treatment, which is a toxic and very expensive therapy. The availability of these drugs is, however, limited. They remain a non-standard form of pharmacotherapy, requiring approval of the payer for treatment reimbursement, or they can only be used as part of controlled clinical trials.

The predictive factors (i.e. those showing a correlation with progression-free survival during the causal treatment) can become an important tool helping in the selection of patients for causative treatment, and additionally, in better assignment of patients to specific therapies. There are ongoing studies on modern markers which may have predictive value in patients with clear-cell renal cell carcinoma. These markers in-
Table 1. Patient group classification based on the presence of risk factors according to MSKCC

\begin{tabular}{|c|c|c|}
\hline Risk groups & $\begin{array}{l}\text { Number of risk } \\
\text { factors }\end{array}$ & $\begin{array}{l}\text { Median } \\
\text { survival }\end{array}$ \\
\hline group A & $\begin{array}{c}\text { no risk factors } \\
\text { (about } 25 \% \text { of patients) }\end{array}$ & 20 months \\
\hline group B & $\begin{array}{c}1-3 \text { risk factors } \\
\text { (about } 53 \% \text { of patients) }\end{array}$ & 10 months \\
\hline group C & $\begin{array}{l}\text { more than } 3 \text { risk factors } \\
\text { (about } 22 \% \text { of patients) }\end{array}$ & 4 months \\
\hline
\end{tabular}

Table 2. Patient group classification according to the cumulative risk scale

\begin{tabular}{|cc|}
\hline Risk groups & Score \\
\hline low risk & 0 points \\
\hline medium risk & $1-3$ points \\
\hline high risk & 4 or more points \\
\hline
\end{tabular}

clude factors that regulate apoptosis, factors induced in states of hypoxia, proliferation markers and cell adhesion-related factors, as well as other factors not included in the above groups, i.e. gelsolin, vimentin, androgen receptor, caveolin 1 [8].

The aim of this article is to identify and describe the new markers that may have predictive and prognostic significance in patients with metastatic RCC on the basis of the available literature, based on the performed solid analyses.

Table 3 presents a classification of prognostic and predictive factors in renal cell carcinoma.

Defects in the process of programmed cell death, or apoptosis, play an important role in the development of carcinogenesis. The process of apoptosis is regulated, among other factors, by the Bcl-2 family and $\mathrm{p} 53$ proteins, as well as the recently discovered family of protein inhibitors of apoptosis (IAP), which includes the following proteins: XIAP, CIAP1, CIAP2, survivin, livin, IL P-2, NAIP, BRUCE. The mechanism of anti-apoptotic action of this family consists in interfering with the apoptotic signal transduction pathway. Most of the IAP

Table 3. Selected markers of potential prognostic and predictive value in kidney cancer

\begin{tabular}{|c|c|c|c|}
\hline $\begin{array}{l}\text { Hypoxia-induced } \\
\text { markers }\end{array}$ & $\begin{array}{l}\text { Markers associated with } \\
\text { cellular adhesion }\end{array}$ & $\begin{array}{l}\text { Cell cycle regulators } \\
\text { Markers of apoptosis }\end{array}$ & Other \\
\hline CAIX - carbonic anhydrase IX & $\begin{array}{l}\text { EpCAM - epithelial cell } \\
\text { adhesion molecule }\end{array}$ & p53 & gelsolin \\
\hline $\begin{array}{l}\text { CXCR-4 - CXC chemokine } \\
\text { receptor-4) }\end{array}$ & $\begin{array}{l}\text { EMA - epithelial membrane } \\
\text { antigen }\end{array}$ & bcl-2 & vimentin \\
\hline $\begin{array}{l}\text { HIF-1 } \alpha \text { - hypoxia-inducible } \\
\text { factor } 1 \alpha\end{array}$ & E-cadherin & $\begin{array}{l}\text { PTEN - phosphatase } \\
\text { and tensin homolog deleted } \\
\text { on chromosome } 10\end{array}$ & androgen receptor \\
\hline $\begin{array}{l}\text { VEGF - vascular endothelial } \\
\text { growth factor }\end{array}$ & $\alpha$-catenin & cyclin A & caveolin 1 \\
\hline $\begin{array}{l}\text { IGF-1 - insulin-like growth } \\
\text { factor } 1\end{array}$ & cadherin 6 & $\begin{array}{l}\text { S6 kinase } \\
\text { p27 }\end{array}$ & $\begin{array}{l}\text { CD } 44 \\
\text { VEGF-R - vascular } \\
\text { endothelial growth factor } \\
\text { receptor }\end{array}$ \\
\hline
\end{tabular}


proteins directly bind to caspases 3 , thus preventing their activation. Some proteins of the IAP family also prevent the activation of initiator caspase 9. Recent studies have shown that some of these proteins also regulate the process of cytokinesis and mitotic spindle formation [9].

Kempkesteffen et al., searching for factors that could have prognostic or predictive significance in renal cell carcinoma, determined the degree of expression of CIAP1 and CIAP2 proteins in the material collected during nephrectomy from 127 patients. The results were referred to the clinical data collected. The follow-up period in the study was 48 months. Overexpression of CIAP1 and CIAP2 proteins was seen in most samples, while in $20 \%$ the expression was lower. The level of CIAP1 expression was correlated with tumour size. It was higher in tumours at a lower clinical stage by TNM classification. Furthermore, low levels of CIAP1 expression in the tumour cells were correlated with a shorter time to relapse, regardless of the tumour size and histological grade. Univariate and multivariate analyses have confirmed the predictive value of the CIAP1 protein in RCC patients [10].

Survivin also belongs to the group of proteins regulating apoptosis. It is a known inhibitor of cellular apoptosis, inhibiting this process by blocking the caspase cascade. This protein was discovered in 1997 by Ambrossini et al. owing to structural homology with other proteins from the IAP family in B-cell lymphoma. Overexpression of this protein was seen in many tumours and it is associated with a poor prognosis. The group of cancers, other than kidney cancer, in which it is detected, includes cancers of the lungs, breast, colon, stomach, oesophagus, pancreas, liver, uterus, ovaries, Hodgkin lymphoma, non-Hodgkin lymphoma, leukaemia, neuroblastoma, phaeochromocytoma, soft tissue sarcoma, glioma and melanoma. Survivin expression is also seen in normal mature tissues but only in a few types of cells, e.g. thymocytes, bone marrow stem cells, CD 34+ and colon epithelial cells [11].

The mechanism of anti-apoptotic activity of survivin also consists in binding of this protein to microtubules of the mitotic spindle, and the inhibition of mitochondrial-dependent apoptosis. It was also shown that, in addition to regulating cell death, survivin plays an important role in cell division [11, 12].

An assessment of the degree of survivin expression in paraffin sections of tumour tissue taken from 85 patients who underwent nephrectomy due to RCC was performed at the Medical University in Seoul. Monoclonal antibodies that reacted immunohistochemically with survivin using the peroxidase-antiperoxidase method were used for the study. The reaction was considered positive if more than $10 \%$ of cells presented the colour effect evaluated under fluorescence microscope. The degree of survivin expression was referred to the clinical features of the tumour. The follow-up period was 45 months. The presence of survivin was noted in 67 (79\%) of 85 samples analysed. A significant increase in survivin expression was correlated with tumour size (T); it also increased with the histological grade $(\mathrm{G})$, and a shorter progression-free survival was seen with higher survivin expression. The degree of tumour cell apoptosis inhibition by survivin was associated with the degree of risk of cancer progression or recurrence. The final conclusion in this study, based on multivariate Cox analysis, was as follows: the degree of survivin expression remained an independent prognostic and predictive factor [13].

A similar conclusion was specified by researchers from the Medical University of Florida, who evaluated the tumour material collected in the period from 1990 to 1994 from 312 patients during nephrectomy performed for clear-cell renal cell carcinoma. The method of assessing the degree of survivin expression was similar as in the study described above. The results of analysis were as follows: 97 (31.1\%) patients had high expression of survivin and in these patients the risk of death was higher compared to other evaluated patients. In addition, 5-year progression-free survival was estimated at $43 \%$ compared to $87.2 \%$ in patients with a low level of survivin expression. As in the study described above, a higher degree of survivin expression was correlated with the clinical stage of the tumour by TNM classification, as well as the histological grade G. In this study, surviving was found to be an independent predictor of progression and death related to kidney tumour growth [14].

Like the other predictors and prognostic factors in this cancer, survivin can provide new information for the patients' selection for new targeted therapies for metastatic clear-cell renal cell carcinoma.

Another marker regulating apoptosis, evaluated in terms of its predictive value in kidney cancer, is p53 protein. p53 gene mutation causes accumulation of $\mathrm{p} 53$ protein in the cell and is seen in many types of cancer. p53 protein has the properties of a tumour suppressor. It is involved in the regulation of many cellular processes, in particular the activation of DNA repair mechanisms, and the induction of apoptosis in response to DNA damage. In the literature, a relationship between the degree of p53 protein expression and tumour progression, and tumour-specific survival, has been described.

Shvarts et al. searched for independent predictive factors in 193 patients with non-metastatic kidney cancer treated with nephrectomy between 1989 and 2000. In the material collected during nephrectomy, using immunohistochemical methods, they evaluated the expression of p53 protein and additionally the following molecular markers: CA9, CA12, Ki-67, gelsolin, vimentin, EpCAM and pTEN. This group of patients was analysed by age, sex, ECOG (Eastern Cooperative Oncology Group) performance status, clinical stage of cancer by TNM classification, histological grade $\mathrm{G}$, and time to cancer relapse or recurrence. The results were as follows: $15 \%$ of patients (29 out of 193) had relapsed after nephrectomy. Univariate Cox analysis showed that tumour size, grade, ECOG performance status, Ki-67, EpCAM and p53 were significantly associated with recurrence of cancer. Based on multivariate Cox analysis it was confirmed that tumour size and the degree of p53 protein expression were the most significant predictors in this group of patients. The degree of p53 protein expression was significantly correlated with the degree of malignancy, but there was no correlation with clinical signs of cancer. In the group of patients with p53 protein expression over 20\%, the recurrence rate was $37.7 \%$ compared to $14.4 \%$ in patients with the expression of this protein below $20 \%$. In conclusion, in patients with low expression of p53 protein, the 5-year progression-free survival was higher compared to the group of patients with high expression of this factor. The authors of this study have shown 
that p53 protein may be considered an important predictor of recurrence in patients undergoing nephrectomy [15].

Phuoc et al. examined the risk of progression in clearcell RCC by assessing the degree of expression of $p 53$ protein and Ki-67, bcl-2, cyclin D1, VEGF and HER-2 in the material collected during nephrectomy from 119 patients in relation to the survival rate. Based on the performed analysis, the authors found that high expression of p53, Ki-67 and VEGF was correlated with shorter survival, whereas high expression of bcl-2 and cyclin-D1 was correlated with longer survival in the study group. Only the expression of HER-2 receptor was not associated with the analysed survival rate. The final conclusion from this study was as follows: among the markers tested, only p53 protein was an independent predictive factor in metastatic clear-cell renal cell carcinoma, and it can be used for planning causative therapy in this group of patients [16].

In the next part of this study, we will present another group of factors that may have predictive or prognostic significance in RCC; it is a group of proteins induced by cellular hypoxia.

\section{References}

1. Eble JN, Sauter G, Epstein JN, Sesterhenn IA. Pathology and genetics of tumorous of the urinary system and male genital organs. IARC Press, Lyon 2004; 9-88.

2. Skoneczna I. Epidemiologia raka nerki. In: Rak nerki. Współczesna diagnostyka i terapia. Szczylik C, Wcisło G (eds.). Termedia, Poznań 2010; 17-22.

3. Wojciechowska U, Didkowska J. Nowotwory złośliwe w Polsce w 2008 roku. Centrum Onkologii - Instytut im. M. Skłodowskiej-Curie, Warszawa 2010

4. Ferlay J, Autier P, Boniol M, Heanue M, Colombet M, Boyle P. Estimates of the cancer incidence and mortality in Europe in 2006. Ann Oncol 2007; 18: 581-92

5. Pascual D, Borque A. Epidemiology of kidney cancer. Adv Urol 2008; 782381

6. Stec R, Wcisło G, Szczylik C. Rola leczenia uzupełniającego w przebiegu raka nerki. Wspolczesna Onkol 2008; 12: 301-7.

7. Szczylik C, Żołnierek J, Nurzyński P. Zalecenia postępowania diagnostycznego i terapeutycznego w raku nerki. Wspolczesna Onkol 2004; 8: 189-99.

8. Ligaj M, Olszewski W. Immunohistochemia w raku nerki. In: Rak nerki. Współczesna diagnostyka i terapia. Szczylik C, Wcisło G (eds.). Termedia, Poznań 2010; 75-90.

9. Grzybowska-Izydorczyk O, Smolewski P. Białka inhibitorowe apop tozy z rodziny inhibitorów apoptozy (IAP) i ich antagoniści: rola biologiczna oraz potencjalne znaczenie w karcinogenezie i celowanej terapii przeciwnowotworowej. Acta Haematol Pol 2009; 40: 593-612.

10. Kempkensteffen C, Hinz S, Christoph F, et al. Expression parameters of the inhibitors of apoptosis CIAP1 and CIAP2 in renal cell carcinomas and their prognostic relevance. Int J Cancer 2007; 120: 1081-6.

11. Li F. Survivin study: what is the next wave? J Cell Physiol 2003; 197 8-29.

12. Altieri DC. Validating survivin as a cancer therapeutic target. Nat Rev Cancer 2003; 3: 46-54

13. Byun SS, Yeo WG, Lee SE, Lee E. Expression of survivin in renal cell carcinomas: association with pathologic features and clinical outcome. Urology 2007; 69: 34-7.

14. Parker AS, Kosari F, Lohse CM, et al. High expression levels of survivin protein independently predict a poor outcome for patients who undergo surgery for clear cell renal cell carcinoma. Cancer 2006; 107: 37-45.

15. Shvarts O, Seligson D, Lam J, Shi T, Horvath S, Figlin R, Belldegrun A, Pantuck AJ. p53 is an independent predictor of tumor recurrence and progression after nephrectomy in patients with localized renal cell carcinoma. J Urol 2005; 173: 725-8.
16. Phuoc NB, Ehara H, Gotoh T, Nakano M, Yokoi S, Deguchi T, Hirose $Y$. Immunohistochemical analysis with multiple antibodies in search of prognostic markers for clear cell renal cell carcinoma. Urology 2007; 69: $843-8$

\section{Address for correspondence}

Beata Młot MD, PhD

Centralny Szpital Kliniczny MON

Wojskowy Instytut Medyczny

Szaserów 128

00-909 Warszawa

e-mail: beatamlot@op.p

Submitted: $\quad 31.03 .2011$

Accepted: $\quad 9.08 .2011$ 